\title{
Estimate of Dietary Total Antioxidant Capacity of Pregnant Women and Associated Factors
}

\section{Estimativa da capacidade antioxidante total da dieta de gestantes e fatores associados}

\author{
Mariana Rinaldi Carvalho ${ }^{1}$ Lívia Castro Crivellenti ${ }^{1}$ Daniela Saes Sartorelli ${ }^{2}$ D \\ ${ }^{1}$ Department of Social Medicine, Public Health Program, Faculdade \\ de Medicina de Ribeirão Preto, Universidade de São Paulo, Ribeirão \\ Address for correspondence Daniela Saes Sartorelli, PhD, Avenida \\ Bandeirantes, 3900, 14049-900, Ribeirão Preto, SP, Brazil \\ Preto, SP, Brazil \\ 2 Department of Social Medicine, Faculdade de Medicina de Ribeirão \\ (e-mail: daniss@fmrp.usp.br) \\ Preto, Universidade de São Paulo, Ribeirão Preto, SP, Brazil \\ Rev Bras Ginecol Obstet 2022;44(2):91-99.
}

\begin{abstract}
Keywords

- total antioxidant capacity

- pregnant women

- diet

- antioxidants

\section{Resumo}

Palavras-chave

- capacidade antioxidante total

- gestantes

- dieta

- antioxidantes

Objective To investigate the dietary total antioxidant capacity (DTAC) of pregnant women, and associated factors.

Methods Cross-sectional study conducted with 785 pregnant adult women attended in primary health care centers of Ribeirão Preto, state of São Paulo, Brazil. Two 24-hour dietary recalls were obtained, and the usual intake was estimated through the Multiple Source Method. The DTAC was estimated using the ferric reducing antioxidant power assay. The relationship between the higher DTAC estimate ( $\geq$ median of $4.3 \mathrm{mmol} /$ day) and associated factors was investigated using adjusted logistic models with backward selection. Results In total, $25 \%$ of the pregnant women were classified as overweight, and $32 \%$ as obese. The median (P25, P75) DTAC was 4.3 (3.3-5.6) mmol/day. Through adjusted logistic regression models with backward selection, a higher chance of DTAC estimates above the median among pregnant women aged $\geq 35$ years old (2.01 [1.24-3.27]) was verified when compared with younger pregnant women. Women with prepregnancy overweight $(0.63$ $[0.45-0.89])$ and obesity $(0.59$ [0.40-0.88]) presented a lower chance of DTAC estimates above the median when compared with eutrophic pregnant women. A higher DTAC estimate was positively associated with the use of dietary supplements (1.39 [1.03-1.88]), and negatively associated with total dietary energy $(0.59$ [0.42-0.85]).

Conclusion The DTAC estimate over the median was associated with greater age, adequate body weight, use of dietary supplements, and lower energy intake.

Objetivo Investigar a capacidade antioxidante total da dieta (CATd) de gestantes e os fatores associados.

Métodos Estudo transversal conduzido entre 785 gestantes adultas em acompanhamento de pré-natal em Unidades Básicas de Saúde de Ribeirão Preto, São Paulo, Brasil. Para a estimativa da dieta usual, 2 inquéritos recordatórios de 24 horas foram obtidos e ajustados empregando-se o Multiple Source Method. A CATd foi estimada com base no ensaio de potência de redução de ferro. Para investigar a relação entre a
\end{abstract}

received

February 22, 2021

accepted

October 5, 2021
DOI https://doi.org/ 10.1055/s-0041-1741454. ISSN $0100-7203$. (c) 2022. Federação Brasileira de Ginecologia e Obstetrícia. All rights reserved.

This is an open access article published by Thieme under the terms of the Creative Commons Attribution License, permitting unrestricted use, distribution, and reproduction so long as the original work is properly cited. (https://creativecommons.org/licenses/by/4.0/)

Thieme Revinter Publicações Ltda., Rua do Matoso 170, Rio de Janeiro, RJ, CEP 20270-135, Brazil 
maior estimativa de CATd ( $\geq$ mediana de $4,3 \mathrm{mmol} / \mathrm{dia}$ ) e os fatores associados, foram empregados modelos de regressão logística ajustados em função backward.

Resultados No total, $25 \%$ das gestantes foram classificadas com sobrepeso e $32 \%$ com obesidade. A mediana (P25; P75) da CATd foi de 4,3 $(3,3-5,6) \mathrm{mmol} / \mathrm{dia}$. Em modelos de regressão logística ajustados em função backward, verificou-se maior chance da estimativa da CATd acima da mediana entre gestantes com idade $\geq 35$ anos (2,01 $[1,24-3,27])$, quando comparadas às gestantes de menor idade. Mulheres com sobrepeso $(0,63[0,45-0,89])$ e obesidade $(0,59[0,40 ; 0,88])$ no período pré-gestacional apresentaram menor chance da estimativa da CATd acima da mediana, quando comparadas às eutróficas. A estimativa da CATd foi positivamente associada ao uso de suplementos dietéticos $(1,39[1,03-1,88])$ e negativamente associada à energia total da dieta $(0,59[0,42-0,85])$.

Conclusão A estimativa da CATd acima da mediana foi positivamente associada à maior idade, eutrofia, ao uso de suplementos dietéticos e à menor ingestão energética.

\section{Introduction}

Maternal nutrition during pregnancy has a great influence on birth outcomes and on the development of chronic diseases in adulthood. ${ }^{1}$ Evidence suggests that adherence to healthy eating patterns composed of foods that are sources of antioxidants, such as fruits, legumes, and vegetables (FLVs), have a protective effect during pregnancy in relation to prematurity and low birth weight (LBW), promoting adequate childhood growth and development. ${ }^{2}$

Numerous vitamins and minerals with antioxidant properties are used to explain the pathway that connects maternal healthy eating behavior with fetal growth. Increased maternal intake of vitamin D supplements reduces the risk of small for gestational age (SGA) infants. ${ }^{3}$ Furthermore, the adequate intake of zinc, magnesium, calcium, and vitamin D supplements is associated with a reduction in oxidative stress in pregnant women with gestational diabetes mellitus (GDM). ${ }^{4}$

Higher levels of reactive oxygen species are physiologically checked during pregnancy and may in fact be important for its organogenesis. ${ }^{5}$ However, excessive production of free radicals associated with a low antioxidant defense can negatively impact the development of the placenta and, consequently, the health of the newborn. ${ }^{5}$ To inhibit and/or reduce the damage caused by the action of free radicals, the human body has enzymatic and nonenzymatic antioxidant defense systems. ${ }^{6}$

The enzymatic defense system includes the enzymes superoxide dismutase, peroxidase, catalase, and glutathione-peroxidase. The activity of these enzymes depends on the participation of nonenzymatic cofactors, the diet being the main contributing factor for the regulation of the serum antioxidant status. $^{7}$

Dietary antioxidants evaluated in isolation may not reflect the total antioxidant power of the diet, as this does not consider the additive or synergistic effects of the interaction between them. Therefore, the dietary total antioxidant capacity (DTAC) has been used to investigate the potential antioxidant effects of foods present in the diet, considering the synergy between them. ${ }^{8}$ The DTAC is recognized as a potential marker of the quality of the usual diet and is positively correlated with the consumption of FLVs, and negatively correlated with the ingestion of fats. ${ }^{9}$

Evidence suggests that the DTAC is directly associated with a lower risk of all-cause mortality, cancer, and cardiovascular disease. ${ }^{10}$ In a study conducted among pregnant women, it was found that women classified in the third tertile of the DTAC estimation had a $46 \%$ lower chance of premature births, regardless of confounding factors. In addition, at an intermediate level, the DTAC was associated with a $75 \%$ lower chance of LBW infants. ${ }^{11}$

Sociodemographic and lifestyle characteristics and the presence of morbidities influence food choices. Studies suggest that older pregnant women, who live with a partner, who perform paid work and have a higher level of education tend to adopt more diverse and healthier diets. ${ }^{12}$ Conversely, it has been observed that younger pregnant women present greater adherence to the patterns of snacks (breads, cheese, sweets, and chocolate, among others). ${ }^{13}$ However, we are unaware of the existence of studies that have investigated the factors associated with higher DTAC estimates in pregnant women.

The aim of the present study was to investigate the factors associated with higher DTAC estimates in pregnant women and to identify the main dietary sources of the DTAC.

\section{Methods}

This is a secondary analysis of a cross-sectional study conducted with 785 adult pregnant women attended at Primary Health Units of the Brazilian National Health System (SUS, in the Portuguese acronym) in the city of Ribeirão Preto, state of São Paulo, Brazil. Conducted between 2011 and 2012, the study aimed to investigate the association between the usual diet during pregnancy and GDM, as described in detail in the publication by Barbieiri et al. ${ }^{14}$ 
The pregnant women were invited to participate in the study when the oral glucose tolerance test (OGTT) was performed. A shift plan was established in five laboratories with the health department of the municipality. All interviews were conducted by previously trained nutritionists. The women that fulfilled the inclusion criteria and agreed to participate in the study were interviewed after signing the consent form.

Fasting blood samples, 1 and 2 hours after ingestion of a 75 g glucose overload, were obtained from all study participants. The glucose oxidase method was used to determine plasma glucose. The diagnosis of GDM was based on the 2014 World Health Organization (WHO) criteria. $^{15}$

The sample size calculation was based on the primary outcome of the study, GDM. Considering a prevalence of $20 \%$ of GDM among adult women attended in the SUS, with an acceptable margin of error of 5\%, a sample of 512 pregnant women was necessary. ${ }^{16}$ Considering that, in logistic regression models, 10 cases are required for each exploratory variable, the sample was considered sufficient for the analysis of the present study. ${ }^{17}$

Women aged $\geq 20$ years, with pregestational BMI $\geq 20 \mathrm{~kg} / \mathrm{m}^{2}$ and screened for GDM from the $24^{\text {th }}$ gestational week were included. Pregnant women diagnosed with previous type 1 or type 2 diabetes mellitus (DM), twin pregnancies, who reported use of drugs that altered blood glucose (such as glucocorticoids) and reported diseases that interfered with their habitual food consumption (chronic renal failure, acquired immunodeficiency syndrome or cancer) were excluded. In total, 1,446 women were invited to participate in the study, with 785 eventually included, as described in - Fig. 1.

The estimation of the diet of the pregnant women was performed by means of 2 24-hour dietary recalls (24hR), following the "multiple-pass" methodology in 3 stages,

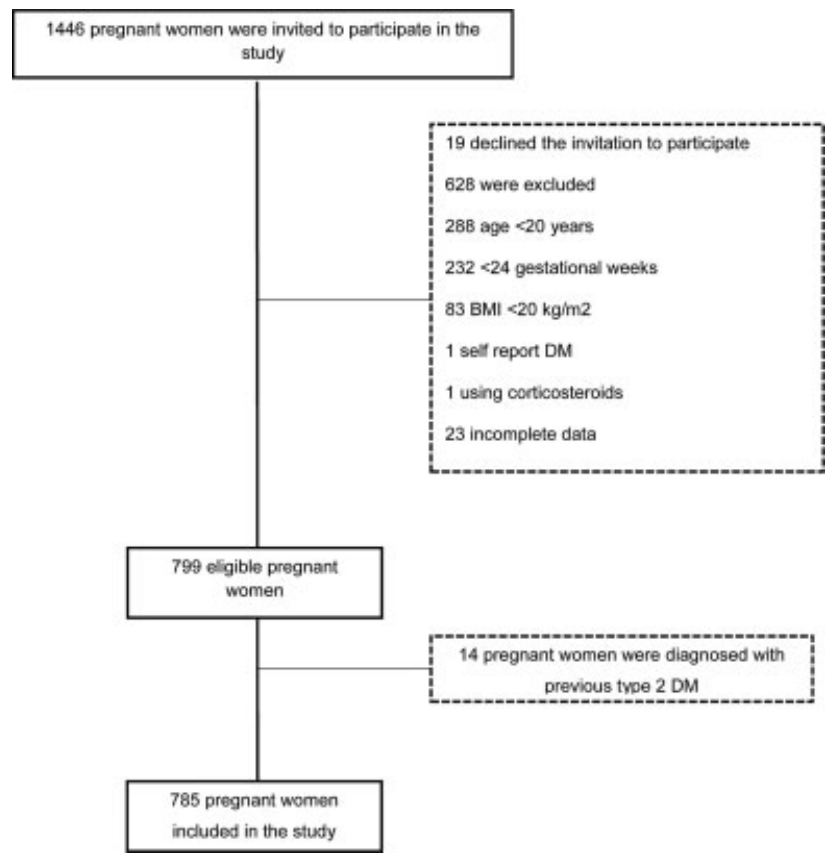

Fig. 1 Flowchart of the study. between the $24^{\text {th }}$ and $39^{\text {th }}$ gestational weeks. The first $24 \mathrm{hR}$ was collected from all pregnant women on the day of the face-to-face interview. ${ }^{18}$ The second $24 \mathrm{hR}$ was obtained from a subsample of $73 \%$ of the pregnant women through telephone contact, on nonconsecutive days, with at least 1 week between replications, regardless of the day of the week or season.

For the estimation of dietary nutrients, the Brazilian Table of Chemical Composition of Food (TACO) was used with the NutWin ${ }^{\circledR}$ Program (Programa de Apoio à Nutrição. Version 1.5. São Paulo: Escola Paulista de Medicina; 2002). ${ }^{19}$ The underreporting of energy intake was estimated using the method by Goldberg et al. ${ }^{20}$, adopting a cutoff point of 1.35 for the ratio between the energy estimate and the basal metabolic rate.

The DTAC (in mmol/100 g), represented by the sum of the TAC of the food and the TAC determined in the supplements, was estimated using data from previous studies that established the total amount of antioxidant present in food and drink through the Ferric Reducing Antioxidant Power assay (FRAP). ${ }^{8,21}$ For foods without TAC determination, the value of a similar food item or of the same botanical group was used: for chicory, endive and arugula, the spinach estimate was used. For red fruits, nectarines and cream, the TAC values of strawberry, peach and butter were used, respectively. For cooked foods that did not have certain TAC values, the value of the fresh food was used. To obtain the TAC value of homemade preparations, previously broken down into ingredients, the calculation of the TAC of each item of the recipe was performed. It was not possible to consider the TAC values of coconut water, salted cod, cane juice, flaxseed, maxixe, sardines, sova, and sushi, as the TAC has not been established for these foods.

The TAC of dietary supplements was estimated by multiplying the amount of antioxidant compound ( $m g$ or IU) present in the capsule by its TAC value ( $\mathrm{mmol} / 100 \mathrm{~g})$. Of the antioxidant compounds present in the dietary supplements, it was not possible to estimate the TAC values of thiamine (B1), riboflavin (B2), nicotinamide (B3), pantothenic acid (B5), and biotin (B7), as the TAC has not been determined for these.

To estimate the usual DTAC, the Multiple Source Method (MSM) was used. This program was developed by the European Prospective Investigation in Cancer and Nutrition (EPIC) (https://msm.dife.de/). ${ }^{22}$ The MSM estimates the usual intake of food and nutrients through the product of the probability of intake and the usual intake, corrected for variability. Correction for variability in intake eliminates the need for a large number of $24 \mathrm{hR}$ replications. The DTAC estimate was adjusted for the total dietary calories using the residual method. ${ }^{23}$

Information on age, self-reported skin color, education of the pregnant woman and of the head of the family, possession of items, occupation, marital status, parity, physical activity, smoking, consumption of alcoholic beverages, and use of dietary supplements was obtained by through a structured questionnaire. For the classification of the economic stratum, the Brazil Economic Classification Criterion was used, which defines the strata from A (highest level) to E (lowest level), based on the possession of items and on the educational level of the head of the family. ${ }^{24}$ 
Weight $(\mathrm{kg})$ and height $(\mathrm{m})$ measurements were obtained using a digital scale (TANITA model HS302 Arlington Heights, Illinois, 60005, USA) and a portable stadiometer (SANNY model ES2040 São Bernardo do Campo, São Paulo, 09628-060, Brazil), respectively. Gestational age was estimated from the date of the last menstrual period recorded on the card of the pregnant woman and was subsequently corrected through ultrasound. Pregestational weight was self-reported and corrected from recording on the card of the pregnant woman. The Institute of Medicine criteria were used to assess the adequacy of pregestational BMI $\left(\mathrm{kg} / \mathrm{m}^{2}\right){ }^{25}$

Descriptive data were presented as mean \pm standard deviation (SD) or median (P25, P75) for continuous variables, and $n$ (\%) for categorical variables. To investigate differences in maternal characteristics according to the DTAC tertiles, the chi-squared test $\left(X^{2}\right)$ was used for the categorical variables and analysis of variance (ANOVA) or the Kruskal-Wallis tests for the continuous variables. The Spearman coefficient was used to investigate the correlation between the DTAC and the food and nutrient groups of the maternal diet.

The factors associated with the higher DTAC estimate ( $\geq 4.3 \mathrm{mmol} /$ day) were investigated in age-adjusted backward logistic regression models (20-25/25-30/30-35/ $\geq 35$ years old), self-reported skin color (white/not white), socioeconomic strata $(A+B / C / D+E)$, living with a partner (yes/no), paid work (yes/no), pregestational BMI $(\mathrm{kg} / \mathrm{m} 2)$, current smoker (no/yes), physical activity ( $<150$ minutes/ $\geq 150$ minutes of walking and/or physical exercises per week), education ( $<4 / 4-8 / \geq 9$ years of study), parity $(<1 /$ $\geq 2$ children), consumption of alcoholic beverages (yes/no), use of food supplement (yes/no), underreport of energy intake (yes/no), total dietary energy (kcal/day tertiles), and gestational trimester at the time of the interview $\left(2^{\text {nd }} / 3^{\text {rd }}\right)$. The associated factors investigated were determined through theoretical assumptions; however, the final models were established based on backward selection.

$P$ values $<.05$ were considered significant. Statistical analyses were performed using the SPSS Statistics for Windows, version 17.0 (SPSS Inc., Chicago, IL, USA).

The present article complies with the ethical principles contained in the Declaration of Helsinki. The study was approved by the Research Ethics Committee of the School Health Center of the Faculdade de Medicina de Ribeirão Preto (Auth. No. 014/2018-CEP/CSE - FMRP - USP).

\section{Results}

In total, 785 pregnant women were investigated. The mean (SD) age of the pregnant women was 28 (5) years old, and the education level varied between zero and 15 years of study. Among them, 25\% were overweight and $32 \%$ were obese. The mean (SD) of the DTAC exclusively from the diet was 4.7 (2.4) $\mathrm{mmol} /$ day, with the mean considering the use of dietary supplements being 4.8 (2.5) $\mathrm{mmol} /$ day. The median (P25, P75) of the DTAC was $4.3(3.3-5.6) \mathrm{mmol} /$ day. Among the women classified in the third tertile of the DTAC, a greater proportion of self-reported white skin color presented a lower mean pregestational BMI when compared with the pregnant women with lower DTAC estimates (- Table 1).

A positive correlation was observed between the DTAC and the estimates of carbohydrates, fiber, vitamin A, vitamin E, folic acid, and the consumption of sugar, coffee and tea, beans, fruits, vegetables, dairy products, breads, and natural fruit juice. Conversely, there was a negative correlation between the DTAC and the consumption of snacks and sandwiches, soft drinks, and artificial juices (-Table $\mathbf{2}$ ).

The main food groups that contributed to the DTAC estimate were coffee and tea (24.12\%), dairy products (21.34\%), fruits, and natural fruit juices (20.37\%) (-Fig. 2).

In the backward logistic regression models, it was found that pregnant women $\geq 35$ years old were twice as likely to have an antioxidant intake above the median when compared with the younger pregnant women. The women that were overweight or obese in the pregestational period had a 37 and $41 \%$ lower likelihood of the DTAC estimate being above the median, respectively, when compared with the eutrophic pregnant women. Those that reported using dietary supplements during pregnancy had a $39 \%$ higher chance of ingesting DTAC above the median when compared with those who did not ingest them. There was also an inverse relationship between total dietary energy intake and the higher DTAC estimate. There was no significant association between the DTAC and the other factors investigated (- Table 3 ).

\section{Discussion}

Among the pregnant women investigated, women $\geq 35$ years old, with pregestational $\mathrm{BMI}<25 \mathrm{~kg} / \mathrm{m}^{2}$, and who reported using dietary supplements during pregnancy had a greater chance of ingesting antioxidants above the median DTAC ( $\geq 4.3 \mathrm{mmol} /$ day). However, it was observed that pregnant women with higher energy intakes had less chance of ingesting antioxidants above the median DTAC ( $\geq 4.3 \mathrm{mmol} /$ day).

The median DTAC observed among the pregnant women using the FRAP method was $4.3 \mathrm{mmol} / \mathrm{day}$, which is much lower than that reported in studies with adults in Spain (17mmoL/day) and France $(13 \mathrm{mmoL} /$ day $){ }^{26,27}$ The findings of the present study agree with previous evidence that suggests a high prevalence of inadequate intake of nutrients with antioxidant properties by pregnant women in Brazil. ${ }^{28}$ The discrepancy in DTAC values observed in the present study, when compared with data from other countries, can be partially explained by the low consumption of fruits and vegetables by the pregnant women in the sample. The mean daily consumption of fruits and vegetables observed was $87.30 \mathrm{~g}$ and $43.37 \mathrm{~g}$, respectively, values well below those recommended by the $\mathrm{WHO}{ }^{29}$

In the present study, the coffee and tea groups (24.12\%), dairy products $(21.34 \%)$, and fruits and natural fruit juices (20.37\%) were the ones that most contributed to the DTAC estimate of the usual diet of the pregnant women. Coffee stood out as the main DTAC source both due to its high antioxidant capacity and its high consumption, corroborating findings of other studies. ${ }^{13,30}$ However, coffee 
Table 1 Sociodemographic and lifestyle characteristics according to tertiles of the estimated dietary total antioxidant capacity of the pregnant women $(n=785)$

\begin{tabular}{|c|c|c|c|c|}
\hline & \multicolumn{3}{|l|}{ DTAC tertiles ${ }^{a}$} & \multirow[t]{2}{*}{ p-value } \\
\hline & T1 $(n=261)$ & $\mathrm{T} 2(n=262)$ & T3 $(n=262)$ & \\
\hline Age (years old) & $27 \pm 5.2$ & $28 \pm 5.7$ & $27.6 \pm 5.51$ & 0.07 \\
\hline White skin color self-reported & $119(45.6)$ & $102(38.9)$ & $131(50.0)$ & 0.04 \\
\hline \multicolumn{5}{|l|}{ Education (years of study) } \\
\hline$<4$ & $8(3.1)$ & $9(3.4)$ & $10(3.8)$ & \multirow[t]{3}{*}{0.13} \\
\hline 4 to 8 & $67(25.7)$ & $84(35.9)$ & $94(32.1)$ & \\
\hline$\geq 9$ & $186(71.3)$ & $159(60.7)$ & $168(64.1)$ & \\
\hline Paid work & $113(43.3)$ & $117(44.8)$ & $134(51.1)$ & 0.16 \\
\hline \multicolumn{5}{|l|}{ Socioeconomic stratum } \\
\hline$A+B$ & $59(22.6)$ & $45(17.2)$ & $50(19.1)$ & \multirow[t]{3}{*}{0.29} \\
\hline C & $175(67.0)$ & $179(68.3)$ & $172(65.6)$ & \\
\hline $\mathrm{D}+\mathrm{E}$ & $27(10.3)$ & $38(14.5)$ & $40(15.3)$ & \\
\hline Living with partner & $209(80.1)$ & $201(76.7)$ & $206(78.6)$ & 0.64 \\
\hline Parity (number of children) & $1.11 \pm 1.21$ & $1.2 \pm 1.29$ & $1.2 \pm 1.19$ & 0.37 \\
\hline Pre-gestational body mass index $\left(\mathrm{kg} / \mathrm{m}^{2}\right)$ & $26.44 \pm 5.6$ & $25.86 \pm 5.6$ & $25.27 \pm 4.5$ & 0.02 \\
\hline Practice physical activity ${ }^{c}$ & $30(0.0 ; 120.0)$ & $45(0.0 ; 140.0)$ & $50(0.0 ; 142.5)$ & 0.14 \\
\hline Current smoker & $24(9.2)$ & $22(8.4)$ & $25(9.5)$ & 0.44 \\
\hline Consumption of alcoholic beverages & $68(26.1)$ & $70(26.7)$ & $59(22.5)$ & 0.50 \\
\hline Use of food supplement & $153(58.6)$ & $170(65.1)$ & $176(67.2)$ & 0.10 \\
\hline Energy (kcal/day) & $1981.55 \pm 554.60$ & $1956.60 \pm 542.23$ & $1926.25 \pm 538.45$ & 0.51 \\
\hline Energy underreport & $136(52.1)$ & $109(41.6)$ & $124(47.0)$ & 0.06 \\
\hline \multicolumn{5}{|l|}{ Gestational trimester at interview } \\
\hline Second & $130(49.8)$ & $147(56.1)$ & $139(53.1)$ & \multirow[t]{2}{*}{0.35} \\
\hline Third & $131(50.2)$ & 115 (43.9) & $123(46.9)$ & \\
\hline
\end{tabular}

Values presented as mean \pm SD or $n(\%)$ or median (P25; P75).

${ }^{a}$ DTAC, Dietary total antioxidant capacity. For the analysis, the DTAC adjusted for the total dietary calories, using the residual method, was considered. T, tertile. TAC (mmol/day) Mean (SD) minimum- maximum: T1 (2.8 [0.62], 0.3-3.6); T2 (4.4 [0.4], 3.6-5.2); T3 (6.9 [2.0], 5.2-21.84). ${ }^{\mathrm{b}} \mathrm{p}<.05$ according to ANOVA test for the continuous variables with normal distribution, Kruskal-Wallis test for the continuous variables without normal distribution, and chi-squared test for the categorical variables.

cMinutes of walking or exercise/week

consumption during pregnancy should be moderate because caffeine is absorbed rapidly upon ingestion and passes the placental barrier leading to higher exposure for the fetus. ${ }^{30}$ Observational studies suggest that excess intake of caffeine may be associated with negative birth results. In a metaanalysis of observational studies, there was a $3 \%$ increase in the risk of babies with low birth weight (LBW) for each additional $100 \mathrm{mg}$ of caffeine consumed per day during pregnancy. $^{31}$

The milk and dairy products group was the second group that most contributed to the determination of the DTAC of pregnant women. Despite the fact that milk is not a relevant source of TAC, a high consumption was verified in the study population. The group of fruits and natural fruit juices was the third that most contributed to the determination of DTAC. However, the mean consumption of fruit by the pregnant women was below that recommended by the WHO, contributing to a low mean intake of antioxidants. ${ }^{29}$
There was a positive correlation between sugar consumption and the DTAC. A possible explanation for this unexpected result is that sugar is commonly added to some of the DTAC source foods by the study population, such as coffee, tea, milk, and natural fruit juices.

The DTAC, in addition to measuring antioxidant intake, can be considered a potential marker of diet quality, allowing a comparison between our results and studies that assessed diet quality using dietary indices. ${ }^{10}$ The data from the present study suggest a higher chance of estimating the DTAC above the median among eutrophic women, in agreement with previous evidence. In a study conducted by Laraia et al., ${ }^{32}$ the pregestational BMI was inversely associated with the quality of the diet of pregnant women, evaluated using the Diet Quality Index for Pregnancy (DQI-P).

A direct relationship between the age of the pregnant women and the DTAC was observed in the present study, corroborating studies that also found better quality diets in 
96 Dietary Total Antioxidant Capacity of Pregnant Women and Associated Factors Carvalho et al.

Table 2 Characteristics of the diet according to the tertiles of the estimated dietary total antioxidant capacity of pregnant women $(n=785)$

\begin{tabular}{|c|c|c|c|c|}
\hline & DTAC tertiles $^{a}$ & & & \\
\hline & $\begin{array}{l}\text { Spearman correlation. } \\
(r)\end{array}$ & $\mathrm{T} 1(n=261)$ & $\mathrm{T} 2(n=262)$ & T3 $(n=262)$ \\
\hline \multicolumn{5}{|l|}{ Nutrients } \\
\hline Carbohydrate (\%TEV) & $0.19^{c}$ & $53(49 ; 58)$ & $54(51 ; 58)$ & $56(52 ; 59)$ \\
\hline Protein (\%TEV) & 0.01 & $16(14 ; 19)$ & $16(14 ; 18)$ & $16(14 ; 18)$ \\
\hline Lipid (\%TEV) & -0.05 & $24(21 ; 28)$ & $24(21 ; 27)$ & $24(21 ; 27)$ \\
\hline Fiber $/ 1000 \mathrm{kcal}$ & $0.22^{\mathrm{c}}$ & $11(8 ; 13)$ & $11(9 ; 14)$ & $12(10 ; 14)$ \\
\hline Vitamin A (mg) & $0.14^{c}$ & $305(219 ; 393)$ & $346(265 ; 468)$ & $345(262 ; 464)^{\mathrm{b}}$ \\
\hline Vitamin B12 (mg) & 0.06 & $4(3 ; 6)$ & $5(3 ; 7)$ & $5(3 ; 6)$ \\
\hline Vitamin C (mg) & 0.32 & $30(13 ; 89)$ & $60(22 ; 137)$ & $102(35 ; 197)^{b}$ \\
\hline Vitamin E (mg) & $0.18^{c}$ & $4(3 ; 5)$ & $4(3 ; 5)$ & $4(4 ; 6)^{b}$ \\
\hline Iron (mg) & 0.05 & $63(8 ; 69)$ & $65(9 ; 69)$ & $65(9 ; 69)$ \\
\hline Zinc (mg) & 0.00 & $10(8 ; 12)$ & $10(8 ; 12)$ & $10(8 ; 12)$ \\
\hline Selenium (mg) & -0.23 & $82(69 ; 95)$ & $80(69 ; 95)$ & 77 (67; 99) \\
\hline Folic Acid $(\mu \mathrm{g})$ & $0.23^{c}$ & $365(302 ; 459)$ & $399(333 ; 490)$ & $429(344 ; 537)^{\mathrm{b}}$ \\
\hline \multicolumn{5}{|l|}{ Foods } \\
\hline Chocolate (g) & -0.02 & $2(1 ; 10)$ & $2(1 ; 21)$ & $1(1 ; 11)^{\mathrm{b}}$ \\
\hline Sugar (g) & $0.37^{c}$ & $2(1 ; 5)$ & $5(2 ; 10)$ & $9(4 ; 14)^{b}$ \\
\hline Rice (g) & -0.04 & $218(150 ; 301)$ & 215 (159; 277) & $201(158 ; 267)$ \\
\hline Coffee/Tea (ml) & $0.49^{c}$ & $8(4 ; 28)$ & $29(6 ; 666)$ & $74(28 ; 111)^{\mathrm{b}}$ \\
\hline Beans (g) & $0.09^{c}$ & $88(52 ; 149)$ & $110(59 ; 149)$ & $102(71 ; 149)$ \\
\hline Fruits (g) & $0.31^{c}$ & $53(31 ; 116)$ & $87(35 ; 160)$ & $132(57 ; 216)^{b}$ \\
\hline Snacks and sandwiches $(\mathrm{g})$ & $-0.13^{c}$ & $11(7 ; 42)$ & $9(6 ; 25)$ & $9(6 ; 13)^{b}$ \\
\hline Legumes (g) & $0.16^{c}$ & $39(24 ; 66)$ & $47(23 ; 78)$ & $57(30 ; 85)$ \\
\hline Milk/Yogurt (ml) & $0.28^{c}$ & $133(38 ; 240)$ & $199(97 ; 277)$ & $221(133 ; 304)^{b}$ \\
\hline Eggs (g) & 0.02 & $2(2 ; 3)$ & $2(2 ; 3)$ & $2(2 ; 3)$ \\
\hline Bread $(g)$ & $0.11^{c}$ & $49(18 ; 55)$ & $54(31 ; 68)$ & $54(29 ; 68)^{\mathrm{b}}$ \\
\hline Soda/Artificial Juice (ml) & $-0.21^{c}$ & $487(230 ; 712)$ & $357(193 ; 580)$ & $314(154 ; 535)^{\mathrm{b}}$ \\
\hline Natural Juice (ml) & $0.16^{c}$ & $3(2 ; 3)$ & $3(3 ; 2)$ & $3(2 ; 171)^{b}$ \\
\hline Root vegetables (g) & 0.01 & $18(11 ; 27)$ & $17(9 ; 39)$ & $18(10 ; 28)$ \\
\hline
\end{tabular}

aDTAC, Dietary total antioxidant capacity. For the analysis, the DTAC adjusted for the total dietary calories, using the residual method, was considered. TAC (mmol/day) Mean (SD) minimum - maximum: T1 (2.8 [0.62], 0.3-3.6); T2 (4.4 [0.4], 3.6-5.2); T3 (6.9 [2.0], 5.2-21.84).

$\mathrm{b}_{p}<.05$ according to the Kruskal-Wallis test (continuous variables without normal distribution).

$c_{p}<.05$ according to Spearman Correlation test $(r)$

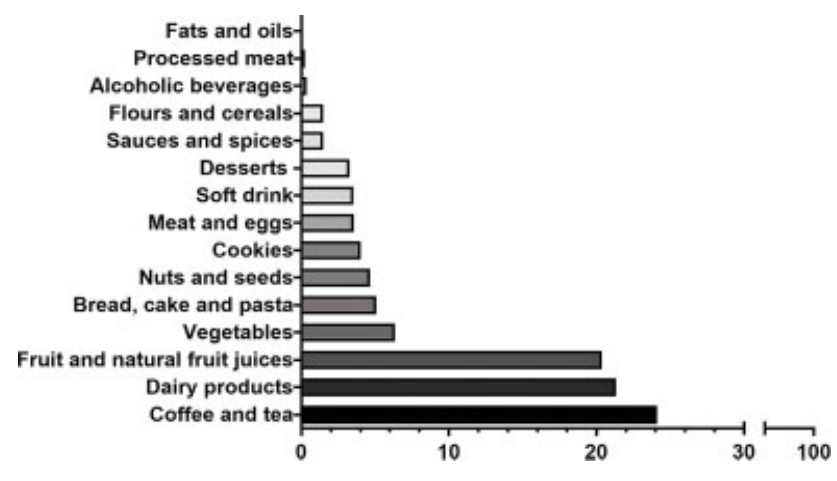

Fig. 2 Main dietary contributors to the DTAC intake of the pregnant women $(n=785)$. older pregnant women. ${ }^{13,33}$ One of these studies, conducted with Brazilian pregnant women, found that older women presented greater adherence to a "healthy" dietary pattern, composed of vegetables and legumes, fruits, and natural fruit juices. ${ }^{14}$

The mean (SD) of the TAC exclusively from the diet was 4.7 (2.4) $\mathrm{mmol} / \mathrm{day}$, with the mean considering the use of dietary supplements being $4.8(2.5) \mathrm{mmol} / \mathrm{day}$. There was a small variation in the DTAC when considering the use of a dietary supplement; however, this showed a direct relationship with the higher median of the DTAC. The combination of dietary sources rich in antioxidants and the use of supplements contributes to favorable health outcomes for the baby. However, further studies in other populations are needed. Pregnant 
Dietary Total Antioxidant Capacity of Pregnant Women and Associated Factors Carvalho et al. 97

Table 3 Factors associated with the determination of the DTAC above the median $(\geq 4.3 \mathrm{mmol} /$ day $)(n=785)$

\begin{tabular}{|c|c|c|c|c|c|c|}
\hline & \multicolumn{6}{|c|}{ Total Antioxidant Capacity ${ }^{a}$} \\
\hline & \multicolumn{3}{|c|}{ Unadjusted model } & \multicolumn{3}{|c|}{ Adjusted model $^{\mathrm{b}}$} \\
\hline & OR & $95 \% \mathrm{Cl}$ & $p$-value & OR & $95 \% \mathrm{Cl} 1$ & p-value \\
\hline Age (years old) & & & .03 & & & 0.02 \\
\hline $20-25$ & 1 & - & & 1 & - & \\
\hline $25-30$ & 1.20 & $0.85-1.69$ & & 1.21 & $0.85-1.72$ & \\
\hline $30-35$ & 1.12 & $0.75-1.65$ & & 1.16 & $0.77-1.73$ & \\
\hline$\geq 35$ & 1.89 & $1.18-3.03$ & & 2.01 & $1.24-3.27$ & \\
\hline Skin color self-reported & & & .24 & & & \\
\hline White & 1 & - & & & & \\
\hline Non-white & 0.84 & $0.64-1.12$ & & & & \\
\hline Socioeconomic stratum & & & .11 & & & \\
\hline$A+B$ & 1 & - & & & & \\
\hline c & 1.06 & $0.74-1.52$ & & & & \\
\hline $\mathrm{D}+\mathrm{E}$ & 1.56 & $0.95-2.57$ & & & & \\
\hline Marital status & & & .61 & & & \\
\hline Married & 1 & - & & & & \\
\hline Single, widowed or separated & 0.91 & $0.65-1.28$ & & & & \\
\hline Working & & & .61 & & & \\
\hline No & 1 & - & & & & \\
\hline Yes & 1.08 & $0.81-1.42$ & & & & \\
\hline Pregestational body mass index & & & .01 & & & 0.003 \\
\hline$<25$ & 1 & - & & 1 & - & \\
\hline $25-29$ & 0.66 & $0.47-0.91$ & & 0.63 & $0.45-0.89$ & \\
\hline$\geq 30$ & 0.66 & $0.45-0.98$ & & 0.59 & $0.40-0.88$ & \\
\hline Current smoker & & & .89 & & & \\
\hline No & 1 & - & & & & \\
\hline Yes & 1.03 & $0.63-1.68$ & & & & \\
\hline Practice physical activity & & & .73 & & & \\
\hline$<150$ minutes & 1 & - & & & & \\
\hline$\geq 150$ minutes & 1.06 & $0.76-1.49$ & & & & \\
\hline Education (years of study) & & & .13 & & & \\
\hline$<4$ & 1 & - & & & & \\
\hline 4 to 8 & 0.86 & $0.39-1.91$ & & & & \\
\hline$\geq 9$ & 0.70 & $0.32-1.52$ & & & & \\
\hline Parity & & & .86 & & & \\
\hline$\leq 1$ & 1 & - & & & & \\
\hline$\geq 2$ & 1.03 & $0.76-1.39$ & & & & \\
\hline Consumption of alcoholic beverages & & & .55 & & & \\
\hline No & 1 & - & & & & \\
\hline Yes & 0.91 & $0.65-1.25$ & & & & \\
\hline Use of food supplement & & & .02 & & & 0.03 \\
\hline No & 1 & - & & 1 & - & \\
\hline Yes & 0.71 & $0.53-0.95$ & & 1.39 & $1.03-1.88$ & \\
\hline Energy underreport & & & .94 & & & \\
\hline No & 1 & - & & & & \\
\hline Yes & 0.98 & $0.74-1.31$ & & & & \\
\hline Total dietary energy $(\mathrm{kcal} / \mathrm{d})^{\mathrm{c}}$ & & & .01 & & & \\
\hline $\mathrm{T} 1$ & 1 & - & & 1 & - & 0.004 \\
\hline $\mathrm{T} 2$ & 0.64 & $0.46-0.91$ & & 0.62 & $0.44-0.89$ & \\
\hline T3 & 0.64 & $0.45-0.90$ & & 0.59 & $0.42-0.85$ & \\
\hline Gestational trimester at the interview & & & .56 & & & \\
\hline $2^{\text {nd }}$ & 1 & - & & & & \\
\hline $3^{\text {rd }}$ & 0.92 & $0.69-1.22$ & & & & \\
\hline
\end{tabular}

${ }^{\mathrm{a} D T A C}$ Adjusted for total dietary calories, using the residual method. Median DTAC $4.3 \mathrm{mmol} /$ day.

bLogistic regression model with age-adjusted backward function (20-25/25-30/30-35/ $\geq 35$ years old), self-reported skin color (white/non-white), socioeconomic strata $(A+B / C / D+E)$, living with partner (yes/no), paid work (yes/no), pre-pregnancy body mass index $\left(\mathrm{kg} / \mathrm{m}^{2}\right)$, current smoker (no/yes), physical activity ( $<150$ minutes/ $\geq 150$ minutes of walking and/or physical exercises/week), education ( $<4 / 4-8 / \geq 9$ years of study), parity $(<1 / \geq 2$ children), consumption of alcoholic beverages (yes/no), use of food supplement (yes/no), underreport of energy intake (yes/no) total dietary energy ( $\mathrm{kcal} /$ day tertiles) and gestational trimester at the time of the interview (second/third).

'Total dietary energy (kcal/d): T1: 644-1695 kcal/d; T2: 1696-2129 kcal/d; T3: 2130-4464 kcal/d. 
women with lower energy intake were more likely to present DTAC estimates above the median. Evidence show that healthier diets are rich in foods with a high nutrient density and low energy density, as they are based on foods of plant origin. Consequently, they are rich in vitamins and minerals with antioxidant properties, as well as rich in fiber. ${ }^{34}$

The present study has some limitations, the main one being its cross-sectional design. The DTAC determination of the diet of the pregnant women was based mainly on an international database, in which the values may vary in relation to the food produced in Brazil, considering the differences in soil and climate. The underreporting of energy intake was estimated using the formula by Goldberg et al. ${ }^{20}$, adopting a cutoff point $\leq 1.35 .^{20}$ The high proportion of underreporting of the diet among the participants in our study (47\%) corroborates an investigation conducted among pregnant women in Ireland, in which the underreporting of energy intake was $42 \%$, even adopting a cutoff $\leq 1.2{ }^{35}$ It is important to note that the method by Goldberg et al. ${ }^{20}$ may not be the best approach to estimate the underreporting of the energy intake during pregnancy, as it does not consider the practice of physical activity of the individual and presupposes the maintenance of body weight. In addition, the cutoff point of the BMI adopted as an inclusion criterion in the study was $\geq 20 \mathrm{~kg} / \mathrm{m}^{2}$, not allowing the extrapolation of data for pregnant women with lower BMI values.

Among the strengths of the present study, its originality stands out. Furthermore, the data collection was performed by trained nutritionists, and the DTAC estimate was performed using $24 \mathrm{hR}$ adjusted through the MSM. Future studies are necessary to confirm the findings of the present study.

\section{Conclusion}

In conclusion, pregnant women $\geq 35$ years old, eutrophic, using dietary supplements, and with lower energy intake had a greater likelihood of presenting DTAC estimates above the median. It should be highlighted that the DTAC of the evaluated pregnant women was the lowest value ever described in the literature, showing the importance of developing public policies that encourage adherence to the recommendations for the consumption of FLVs during the different life cycles.

\section{Contributions}

Carvalho M. R., Crivellenti L. C. and Sartorelli D. S. contributed to the design and planning of the study. Data collection was performed by Crivellenti L. C. and Sartorelli D. S.. The analysis and interpretation of the data was performed by Carvalho M. R. and Sartorelli D. S.. The first version of the manuscript was written by Carvalho M. R. and was revised by Crivellenti L. C. and Sartorelli D. S.. All authors approved the final version of the manuscript and are responsible for the content of the article.

\section{Conflict of Interests}

The authors have no conflict of interests to declare.

\section{Acknowledgments}

The present research was supported by the National Council for Scientific and Technological Development (302498/2015-0 and 472221/2010-8), the Coordination for the Improvement of Higher Education Personnel (CAPES, in the Portuguese acronym) (1731372), São Paulo Research Foundation (FAPESP, in the Portuguese acronym, 2017/18980-2), Foundation for Support to Teaching, Research and Assistance at the Clinical Hospital of the Ribeirão Preto School of Medicine, University of São Paulo (FAEPA in the Portuguese acronym), and the Research Department of the University of São Paulo (Project 1, USP), Brazil.

\section{References}

1 Chia AR, Chen LW, Lai JS, Wong CH, Neelakantan N, van Dam RM, et al. Maternal dietary patterns and birth outcomes: a systematic review and meta-analysis. Adv Nutr. 2019;10(04):685-695. Doi: 10.1093/advances/nmy123

2 Kibret KT, Chojenta C, Gresham E, Tegegne TK, Loxton D. Maternal dietary patterns and risk of adverse pregnancy (hypertensive disorders of pregnancy and gestational diabetes mellitus) and birth (preterm birth and low birth weight) outcomes: a systematic review and meta-analysis. Public Health Nutr. 2018;22(03): 1-15. Doi: $10.1017 /$ S1368980018002616

3 Roth DE, Leung M, Mesfin E, Qamar H, Watterworth J, Papp E. Vitamin D supplementation during pregnancy: state of the evidence from a systematic review of randomised trials. BMJ. 2017; 359:j5237. Doi: 10.1136/bmj.j5237

4 Jamilian M, Mirhosseini N, Eslahi M, Bahmani F, Shokrpour M, Chamani M, et al. The effects of magnesium-zinc-calcium-vitamin D co-supplementation on biomarkers of inflammation, oxidative stress and pregnancy outcomes in gestational diabetes. BMC Pregnancy Childbirth. 2019;19(01):107. Doi: 10.1186/s12884-019-2258-y

5 Aouache R, Biquard L, Vaiman D, Miralles F. Oxidative stress in preeclampsia and placental diseases. Int J Mol Sci. 2018;19(05): 1496. Doi: $10.3390 /$ ijms 19051496

6 Birben E, Sahiner UM, Sackesen C, Erzurum S, Kalayci O. Oxidative stress and antioxidant defense. World Allergy Organ J. 2012;5 (01):9-19. Doi: 10.1097/WOX.0b013e3182439613

7 Li Y, Guo H, Wu M, Liu M. Serum and dietary antioxidant status is associated with lower prevalence of the metabolic syndrome in a study in Shanghai, China. Asia Pac J Clin Nutr. 2013;22(01):60-68. Doi: 10.6133/apjcn.2013.22.1.06

8 Carlsen MH, Halvorsen BL, Holte K, Bøhn SK, Dragland S, et al. The total antioxidant content of more than 3100 foods, beverages, spices, herbs and supplements used worldwide. Nutr J. 2010;9:3. Doi: 10.1186/1475-2891-9-3

9 Puchau B, Zulet MA, de Echávarri AG, Hermsdorff HH, Martínez JA. Dietary total antioxidant capacity: a novel indicator of diet quality in healthy young adults. J Am Coll Nutr. 2009;28(06):648-656. Doi: 10.1080/07315724.2009.10719797

10 Parohan M, Anjom-Shoae J, Nasiri M, Khodadost M, Khatibi SR, Sadeghi O. Dietary total antioxidant capacity and mortality from all causes, cardiovascular disease and cancer: a systematic review and dose-response meta-analysis of prospective cohort studies. Eur J Nutr. 2019;58(06):2175-2189. Doi: 10.1007/s00394-01901922-9

11 Sartorelli DS, Carvalho MR, da Silva Santos I, Crivellenti LC, Souza JP, Franco LJ. Dietary total antioxidant capacity during pregnancy and birth outcomes. Eur J Nutr. 2021;60(01):357-367. Doi: 10.1007/s00394-020-02251-y

12 Gomes CDB, Vasconcelos LG, Cintra RMGDC, Dias LCGD, Carvalhares MADBL. Hábitos alimentares das gestantes brasileiras: 
revisão integrativa da literatura. Ciênc Saúde Coletiva. 2019;24 (06):2293-2306. Doi: 10.1590/1413-81232018246.14702017

13 Zuccolotto DCC, Crivellenti LC, Franco LJ, Sartorelli DS. Dietary patterns of pregnant women, maternal excessive body weight and gestational diabetes. Rev Saude Publica. 2019;53:52. Doi: 10.11606/s1518-8787.2019053000909

14 Barbieiri P, Nunes JC, Torres AG, Nishimura RY, Zuccolotto DCC, Crivellenti LC, et al. Indices of dietary fat quality during midpregnancy is associated with gestational diabetes. Nutrition. 2016;32 (06):656-661. Doi: 10.1016/j.nut.2015.12.002

15 Diagnostic criteria and classification of hyperglycaemia first detected in pregnancy: a World Health Organization Guideline. Diabetes Res Clin Pract. 2014;103(03):341-363. Doi: 10.1016/j. diabres.2013.10.012

16 Trujillo J, Vigo A, Duncan BB, Falavigna M, Wendland EM, Campos MA, et al. Impact of the International Association of Diabetes and Pregnancy Study Groups criteria for gestational diabetes. Diabetes Res Clin Pract. 2015;108(02):288-295. Doi: 10.1016/j.diabres.2015.02.007

17 Peduzzi P, Concato J, Kemper E, Holford TR, Feinstein AR. A simulation study of the number of events per variable in logistic regression analysis. J Clin Epidemiol. 1996;49(12):1373-1379. Doi: 10.1016/s0895-4356(96)00236-3

18 Johnson RK, Soultanakis RP, Matthews DE. Literacy and body fatness are associated with underreporting of energy intake in US low-income women using the multiple-pass 24-hour recall: a doubly labeled water study. J Am Diet Assoc. 1998;98(10): 1136-1140. Doi: 10.1016/S0002-8223(98)00263-6

19 Universidade Estadual de Campinas. Núcleo de Estudos e Pesquisas em Alimentação. Tabela brasileira de composição de alimentos: TACO 2. ed. Campinas: NEPA-UNICAMP; 2006

20 Goldberg GR, Black AE, Jebb SA, Cole JT, Murgatroyd PR, Coward WA, et al. Critical evaluation of energy intake data using fundamental principles of energy physiology: 1. Derivation of cut-off limits to identify under-recording. Eur J Clin Nutr. 1991;45(12):569-581

21 Rufino MS, Alves RE, Brito ES, Pérez-Jiménez J, Saura-Calixto F, Mancini-Filho J. Bioactive compounds and antioxidant capacities of 18 non-traditional tropical fruits from Brazil. Food Chem. 2010; 121(04):996-1002. Doi: 10.1016/j.foodchem.2010.01.037

22 Harttig U, HaubrockJ, Knüppel S, Boeing H. The MSM program: webbased statistics package for estimating usual dietary intake using the Multiple Source Method. Eur J Clin Nutr. 2011;65(Suppl 1) S87-S91. Doi: $10.1038 /$ ejcn.2011.92

23 Willett WC. Nutritional epidemiology. 2nd ed. New York: Oxford University Press; 1998

24 Ministério da Saúde. Secretaria de Vigilância em Saúde. Vigitel Brasil 2011: vigilância de fatores de risco e proteção para doenças crônicas por inquérito telefônico: estimativas sobre frequência e distribuição sociodemográfica de fatores de proteção para doenças crônicas nas capitais dos 26 estados brasileiros e no Distrito Federal em 2011 [Internet]. Brasília (DF): Ministério da Saúde 2012 [cited 2021 Feb 15]. Available from: http://bvsms.saude.gov.br/bvs/publicacoes/vigitel_brasil_2011_fatores_risco_doencas_cronicas.pdf

25 Suitor CW. Perspectives on nutrition during pregnancy: Part I, Weight gain; Part II, Nutrient supplements. J Am Diet Assoc. 1991; 91(01):96-98. Doi: 10.1016/S0002-8223(21)01073-7

26 Henríquez-Sánchez P, Sánchez-Villegas A, Ruano-Rodríguez C, Gea A, Lamuela-Raventós RM, Estruch R, et al. Dietary total antioxidant capacity and mortality in the PREDIMED study. Eur J Nutr. 2016;55(01):227-236. Doi: 10.1007/s00394-015-0840-2

27 Bastide N, Dartois L, Dyevre V, Dossus L, Fagherazzi G, Serafini M, et al. Dietary antioxidant capacity and all-cause and causespecific mortality in the E3N/EPIC cohort study. Eur J Nutr. 2017;56(03):1233-1243. Doi: 10.1007/s00394-016-1172-6

28 Malta MB, Carvalhaes MA, Parada CM, Corrente JE. Utilização das recomendações de nutrientes para estimar prevalência de consumo insuficiente das vitaminas C e E em gestantes. Rev Bras Epidemiol. 2008;11(04):573-583. Doi: 10.1590/S1415$790 \times 2008000400006$

29 Amine EK, Baba NH, Belhadj M, et al. Diet, nutrition and the prevention of chronic diseases. Geneva: WHO; 2003. (World Health Organization Technical Report Series; no. 916).

30 Kobayashi S, Asakura K, Suga H, Sasaki SThree-generation Study of Women on Diets and Health Study Groups. Inverse association between dietary habits with high total antioxidant capacity and prevalence of frailty among elderly Japanese women: a multicenter cross-sectional study. J Nutr Health Aging. 2014;18(09): 827-839. Doi: 10.1007/s12603-014-0478-4

31 Rhee J, Kim R, Kim Y, Tam M, Lau Y, Keum N, et al. Maternal caffeine consumption during pregnancy and risk of low birth weight: a dose-response meta-analysis of observational studies. PLoS One. 2015;10(07):e0132334. Doi: 10.1371/journal.pone.0132334

32 Laraia BA, Bodnar LM, Siega-Riz AM. Pregravid body mass index is negatively associated with diet quality during pregnancy. Public Health Nutr. 2007;10(09):920-926. Doi: 10.1017/ S1368980007657991

33 Shin D, Lee KW, Song WO. Dietary patterns during pregnancy are associated with gestational weight gain. Matern Child Health J. 2016;20(12):2527-2538. Doi: 10.1007/s10995-016-2078-x

34 Ledikwe JH, Blanck HM, Kettel Khan L, Serdula MK, Seymour JD, Tohill BC, et al. Dietary energy density is associated with energy intake and weight status in US adults. Am J Clin Nutr. 2006;83 (06):1362-1368. Doi: 10.1093/ajcn/83.6.1362

35 McGowan CA, McAuliffe FM. Maternal nutrient intakes and levels of energy underreporting during early pregnancy. Eur J Clin Nutr. 2012;66(08):906-913. Doi: 10.1038/ejcn.2012.15 